DOI: $\underline{10.35619 / \text { iiu.v1i10.193 }}$

Цимбал-Слатвінська Світлана кандидат педагогічних наук, доцент, доцент кафедри спеціальної освіти Уманського державного педагогічного університету імені Павла Тичини, м. Умань, Україна ORCID: 0000-0002-2732-5716 e-mai:lanatsimbal@gmail.com

\title{
ТЕНДЕНЦЇ̈ ПРОФЕСІЙНОЇ ПІДГОТОВКИ МАЙБУТНІХ ЛОГОПЕДІВ В УМОВАХ ІНФОРМАЦЙНО-ОСВІТНЬОГО СЕРЕДОВИЩА ЗАКЛАДІВ ВИЩОЇ ОСВІТИ
}

\begin{abstract}
Анотація. У статті визначено тенденції професійної підготовки майбутніх логопедів в умовах інформаційно-освітнього середовища закладів вищої освіти: соціально-педагогічна зумовленість процесу підготовки майбутніх логопедів, яка орієнтована на міждисциплінарну інтеграцію в освітньому процесі; фундаменталізація загальної та спеціальної підготовки майбутніх логопедів; переорієнтація зі знаннєвої освітньої парадигми на діяльнісну, орієнтовану на формування готовності майбутнього логопеда до професійної діяльності; гуманістична спрямованість процесу підготовки фахівців до освіти дітей 3 порушеннями мовлення; інформатизація професійної підготовки майбутніх логопедів в умовах інформаційно-освітнього середовища; неперервність професійної підготовки майбутніх логопедів; інноваційний характер сучасної вищої освіти. До специфічних тенденцій професійної підготовки майбутнього логопеда віднесено такі: переорієнтацію ціннісних смислів, інтенсифікацію освіти, необхідність управління педагогічним процесом, кризу спеціальної освіти, що складається під дією зовнішніх i внутрішніх чинників. Основою професійної компетентності логопеда $є$ фундаментальні знання і вироблені на їхній основі вміння, які виступають, безумовно, в тісному єднанні з його особистісними якостями.

У результаті системного аналізу традиційної практики освіти виявлено низку проблем і суперечностей, характерних для лінійної освітньої системи, незалежно від індивідуальних особливостей i властивостей іiі суб'єктів. Серед них: проблема визначення мети в освіті; проблема відбору змісту освіти; проблема організації процесу навчання; проблема інтенсифікації процесу навчання в умовах переважаючої фронтальної взаємодії викладача та студентської групи.
\end{abstract}

Ключові слова: тенденції, професійна підготовка, майбутні логопеди, міждисциплінарна інтеграція, фундаменталізація, гуманістична спрямованість, інформатизація, неперервність.

Постановка проблеми. Одним із напрямів професійної підготовки майбутніх логопедів в умовах інформаційно-освітнього середовища закладів вищої освіти $\epsilon$ постійна робота 3 усвідомлення ними реальних цілей корекційної роботи, іії наукового обгрунтування та пошуку шляхів самовдосконалення.

Аналіз останніх досліджень 3 проблеми. У сучасних педагогічних дослідженнях спостерігається стійкий інтерес авторів до проблеми підготовки майбутніх логопедів до професійної діяльності (В. Акименко, С. Архипова, Т. Бойко, Н. Болтакова, Е. Борисова, Е. Волкова, Ю. Жаркова, Е. Маринич, О. Мартинчук, І. Омельченко, Н. Пахомова, Ф. Рау, М. Ромусик, О. Таран, Л. Федорович, Н. Харченко, Л. Черніченко, Е. Чухачева, С. Шаховська та ін.).

Зміни в завданнях i характері навчання студентів у закладі вищої освіти 
обумовлені глобальними освітніми тенденціями, які отримали назву «мегатенденції» (D. Lowton, S. Shishov). До них автори відносять: масовий характер освіти і іiі неперервність; значущість як для індивіда, так і для суспільних очікувань і норм; орієнтація на активне освоєння людиною способів пізнавальної діяльності; адаптація освітнього процесу до запитів і потреб особистості; орієнтація навчання на особистість учня, забезпечення можливостей його саморозкриття (Lowton D., 1987; Shishov S., 1997).

Мета статті: висвітлити тенденції професійної підготовки майбутніх логопедів в умовах інформаційно-освітнього середовища закладів вищої освіти.

Виклад основного матеріалу дослідження. У професійній підготовці майбутніх логопедів на основі аналізу наукових фактів і широкого педагогічного досвіду виділено такі основні тенденції: 1) соціально-педагогічну зумовленість процесу підготовки майбутніх логопедів, яка орієнтована на міждисциплінарну інтеграцію в освітньому процесі; 2) фундаменталізацію загальної та спеціальної підготовки майбутніх логопедів; 3) переорієнтацію зі знаннєвої освітньої парадигми на діяльнісну, орієнтовану на формування готовності майбутнього логопеда до професійної діяльності; 4) гуманістичну спрямованість процесу підготовки фахівців до освіти дітей 3 порушеннями мовлення; 5) інформатизацію професійної підготовки майбутніх логопедів в умовах інформаційно-освітнього середовища; 6) неперервність професійної підготовки майбутніх логопедів; 7) інноваційний характер сучасної вищої освіти.

Сучасна ситуація соціального розвитку, соціально-педагогічні умови в системі загальної та професійної освіти визначають загальну тенденцію підготовки майбутнього логопеда до освіти дітей з порушеннями мовлення. У той же час вимоги до їхньої підготовки закладають основи такої тенденції, як соціально-педагогічна зумовленість процесу підготовки майбутніх логопедів, що орієнтована на міждисциплінарну інтеграцію в освітньому процесі.

Актуальності набуває осмислення процесів взаємопроникнення знань та руху їх до єдності завдяки використанню такого ресурсу, як інтеграція, покликаної впорядкувати загальні і спеціальні знання в цілісну систему, упорядковану різноманітними відношеннями та взаємозв'язками. Виникнення нових дисциплін, теорій, концепцій інтегрованого характеру відображає синтез взаємодіючих знань та багатоаспектне переплетіння проблем, предметів і методів пізнавальної діяльності, що підтверджує взаємозалежність усіх сфер пізнання міждисциплінарної інтеграції (Пахомова, 2012, с. 181).

Аналіз вимог до рівня підготовки майбутніх логопедів, вивчення практики діяльності закладів освіти свідчать про необхідність комплексної інтегрованої підготовки логопеда до корекційно-педагогічної діяльності з дітьми 3 порушенням мовлення. Якщо загальна професійна підготовка логопеда пов'язується 3 його загальнокультурною освітою, 3 необхідністю розширення його кругозору, усвідомлення ним загальних законів розвитку суспільства і людини, необхідністю морально-правової та духовно-моральної підготовки, розумінням ним основних положень законодавства, вмінням захистити не тільки свої права, а й права дитини, то сьогоднішній стан здоров'я дітей змушує логопеда звертатися до медико-біологічних знань, опановувати елементарні вміння, що сприяють розвитку здорового способу життя дитини та її соціалізації.

Для роботи 3 дітьми потрібні професіонали, які володіють основами знань у галузі суміжних наук, добре орієнтуються в питаннях корекційної педагогіки, спеціальної та клінічної психології, а також соціальної психології. Важливим є вміння педагогів взаємодіяти $з$ дітьми, один $з$ одним і з іншими фахівцями у процесі роботи (Шамова, 2006).

Проблема професійного становлення особистості у закладі вищої освіти безпосередньо пов'язана $з$ проблемою якості освіти, яку Р. Султанова, С. Шишов 
розглядають як соціальну категорію, яка визначає стан і результативність процесу освіти в суспільстві (Шишов, 2000), іiі відповідність потребам та очікуванням суспільства (різних соціальних груп) у розвитку та формуванні громадянських, побутових і професійних компетентностей особистості (Султанова, 2005). Проблема полягає в тому, щоб визначити ті знання, які б забезпечили формування необхідних компетентностей.

3 усього сказаного випливає, що основою професійної компетентності логопеда $\epsilon$ фундаментальні знання і вироблені на їхній основі вміння, які постають, безумовно, в тісному єднанні з його особистісними якостями (Бессмертная, 2001).

Оволодіння професійними компетентностями можливе в тому випадку, якщо в ході підготовки забезпечується фундаменталізація психолого-педагогічних, медичних і соціальних знань на основі практичної діяльності та продовжується процес інтеграції теоретичних і прикладних знань та вмінь, відкривається перспектива формування цілісної особистості спеціаліста (Аслаева, 2011).

Для того, щоб ефективно виконувати свою роботу, необхідно знати ії сутність і як вона здійснюється, тобто другою тенденцією в підготовці майбутнього логопеда $\epsilon$ фундаменталізація його загальної та спеціальної підготовки.

Питання фундаменталізації освіти розглядалось у педагогічній літературі неодноразово (В. Андрющенко, В. Бєліков, Н. Бібік, Я. Болюбаш, Л. Ващенко, О. Вознюк, Б. Гершунський, В. Журавський, I. Зязюн, М. Кларін, В. Кремень, М. Степко, Ю. Татур та ін.). Аналіз публікацій показує, що основою фундаменталізації в них проголошуються методологічно важливі, інваріантні ідеї, які сприяють цілісному сприйняттю наукової картини світу, відповідні інтелектуальному розвитку особистості, іiї адаптації у швидко мінливих соціально-економічних умовах. Слідом за провідними дослідниками вважаємо, що основою професійної освіти майбутнього логопеда повинна бути ідея фундаменталізації - глибина і широта загальнонаукових, філософських, загальнокультурних і спеціальних знань. Спираючись на засвоєні знання через актуальну пізнавальну активність до майбутніх професійних ситуацій така парадигма сучасної професійної підготовки майбутнього логопеда.

Фундаментальність $€$ інструментом досягнення готовності майбутнього логопеда до професійної діяльності і, перш за все орієнтована на пізнання глибинних, сутнісних підстав і зв'язків між різноманітними процесами та явищами. Так, Н. Тализіна вважає, що фундаментальність освіти - генеральний шлях підготовки фахівця: «Підготовка фахівців на базі фундаментальних наук, природно, не означає зниження уваги до професійних видів діяльності. Але вивчення фундаментальних наук не повинно бути поставлено на рівні з професійними предметами: фундаментальні науки повинні орієнтувати фахівця у своїй галузі, дозволяти йому не тільки самостійно аналізувати наявні в ній накопичення, але й передбачити ії подальший розвиток» (Талызина, 1986).

Третя тенденція пов'язана з переорієнтацією зі знаннєвої освітньої парадигми на діяльнісну, спрямовану на формування готовності майбутніх логопедів до професійної діяльності.

В останні роки в педагогічній науці і практиці відбувається переосмислення концептуальних підходів до навчання і виховання молодого покоління, і в нових соціально-економічних умовах предметні знання й навички не охоплюють повний діапазон результатів освіти, необхідних для людського й соціального розвитку, політичного й економічного управління. «Знаннєвий» диктат особливо утвердився в умовах традиційного монодидактизму і недіалогічного характеру освітнього процесу. За такого підходу основним освітнім завданням вважалося формування в студентів систематизованих знань (уміння й навички виступали другорядними компонентами). Зараз акценти зміщуються: основна мета освіти полягає у формуванні здатності до активної діяльності, до праці у всіх іiі формах, особливо професійно-творчих (Харченко, 2003). 
Спостерігається зміщення завдань освіти зі знаннєвої орієнтації в бік розвитку особистості, формування іiі компетентностей у процесі діяльності, переміщення конкуренції в галузь освіти (перехід від інформативних до активних методів і форм навчання із включенням у діяльність студентів елементів проблемності, наукового пошуку, різноманітних форм самостійної роботи - перехід від діяльності з відтворення до розуміння і мислення - перехід до такої організації взаємодії педагога і студентів, за якої акцент переноситься з навчальної діяльності викладача на пізнавальну діяльність суб'єкта навчання.

Переорієнтація освітнього процесу в закладі вищої освіти абсолютно очевидна i, як нам уявляється, пов'язана з вирішенням таких основних проблем: побудови системи знань студентів, необхідної і достатньої для повноцінного оволодіння ними основами професійної діяльності; встановлення взаємозв'язку чуттєвих i раціональних (теоретичних) знань, що лежать в основі оволодіння діяльністю; удосконалення системи знань про діяльність, іiі цілі, способи, засоби та умови; пошуку можливих шляхів підвищення рівня узагальненості знань про діяльність; пошуку способів реалізації практичних потреб, ціннісних орієнтацій студентів у процесі формування теоретичних знань; пошуку шляхів розширення можливостей застосування теоретичних знань у практичній діяльності здобувачів освіти.

Вирішення перерахованих проблем безпосередньо стосується підготовки майбутнього логопеда i, зокрема, тієї іï частини, яка пов'язана 3 його логопедичною освітою, та іï результату - готовністю до професійної діяльності.

Аналіз сучасних тенденцій розвитку вищої освіти свідчить про те, що на перший план виходять проблеми гуманізації та гуманітаризації, утвердження людської гідності і здібностей як основного ресурсу розвитку культури, суспільства й держави. Саме розвиток творчої індивідуальності майбутнього фахівця $\epsilon$ надзвичайно важливим напрямом модернізації системи вищої освіти як соціальний і культурний процес, що включає роботу зі створення нової системи цінностей і нових моделей освіти (Султанова, 2005).

Відповідно четвертою тенденцією називаємо гуманістичну спрямованість процесу підготовки фахівців до освіти дітей з порушеннями мовлення.

На відміну від панівного технократичного підходу, сьогодні актуалізована «гуманістична парадигма» педагогічної освіти, сутність якої визначається самою гуманістичною природою педагогічної діяльності, в центрі якої перебуває особистість як «самоцінність», яка є не тільки повноцінною, але й має різні відхилення: фізичні, деякі психічні або поведінкові (Сластёнин, 1994).

Нова парадигма освіти, орієнтована на почуття власної гідності людини, почуття свободи, професійної компетентності, вимагає переосмислення педагогічною громадськістю концептуальних аспектів організації сучасних освітніх середовищ. У зв'язку з цим необхідно переглянути стилі, методи і форми педагогічної взаємодії, а також спроєктувати взаємини суб'єктів освітнього процесу (Гурниковская, 2006).

Одночасно зростає розуміння того, що традиційна схема отримання освіти застаріла і потребує заміни. Дійсно, звертаючись до традиційних уявлень про освіту, ми неминуче стикаємося 3 категорією «процес», який передбачає наявність єдиної логіки викладання й навчання, за якого взаємодія викладача зі студентом носить абсолютний характер, а всі інші форми діяльності та взаємодії виконують допоміжну функцію. Незалежно від емоційних оцінок традиційна система навчання у закладі вищої освіти $є$ лінійною системою (процесом), ії лінійність проявляється в декількох значеннях: послідовність у викладі нової інформації та її подальшого практичного відпрацювання; регламентація діяльності викладача і студента відповідно до деяких попередньо розроблених планів (інформаційна закритість і замкнутість освітнього процесу); відсутність або неефективність взаємодії між студентами у процесі навчання тощо. 
У результаті системного аналізу традиційної практики освіти виявлено низку проблем і суперечностей, характерних для лінійної освітньої системи, незалежно від індивідуальних особливостей i властивостей іiі суб'єктів. Серед них: проблема визначення мети в освіті (державний стандарт визначає єдині цілі для всіх студентів за умови, що індивідуальні здібності й домагання у різних студентів відрізняються); проблема відбору змісту освіти (проблема диференціації та індивідуалізації змісту освіти в традиційній системі до цього часу не має задовільного вирішення, крім того, сучасні потреби ринку в багатьох випадках істотно відрізняються від сформованих традицій і підходів у визначенні структури та змісту освіти); проблема організації процесу навчання (єдина логіка руху «від простого до складного» виявляється важко здійснюваною, оскільки кожен суб'єкт характеризується домінуванням деяких певних способів сприйняття і схильністю до роботи в своєму темпі); проблема інтенсифікації процесу навчання в умовах переважаючої фронтальної взаємодії викладача та студентської групи.

Ідея нашої роботи полягає в переході від процесуального опису освітніх систем, заснованих на лінійних принципах, до категорії інформаційно-освітнього середовища, що включає все різноманіття суб'єктів освітньої діяльності (викладача і студентів), засобів i, найголовніше, - взаємодій між ними.

Виділимо основні проблеми, напрями й тенденції в тому, що відбувається у вітчизняній вищій школі 3 їх переосмисленням. Насамперед, змінюється загальна цільова установка: в умовах інформаційно-освітнього середовища викладач не може гарантувати досягнення всіма студентами однакового рівня оволодіння матеріалом, більше того, таке завдання, навіть якщо і було б поставлене, не мало б сенсу. Дійсно, в сучасному освітньому просторі, що характеризується безперервним багаторівневим діалогом між усіма його суб'єктами, досягнення індивідуального «всезнання» не $\epsilon$ пріоритетом. Найбільш значним виявляється формування компетентностей, що дозволяють кожному суб'єктові в ситуації знаходити необхідні знання, освоювати їх і здійснювати рефлексію отриманих результатів.

Відповідно, основною освітньою метою стає: створення умов для досягнення кожним студентом оптимального розуміння, застосування та комунікації у відповідній предметній галузі, зокрема логопедії. У зв'язку з цим відбуваються зміни змісту інших категорій: змісту, засобів, моделей освітньої взаємодії, критеріїв і системи діагностики якості освіти, проте найбільших змін зазнає концепція суб'єкта і суб'єктності в підготовці майбутніх логопедів. Тією мірою, якою інформаційно-освітня система забезпечує студента необхідною інформацією, стимулює до постановки уточнювальних питань і контролює ефективність діяльності (реалізує активний інтерфейс), їхня взаємодія $є$ міжсуб'єктною, що вимагає введення своєрідного «віртуального суб'єкта». Відповідно, виникає принципове питання про якісну i кількісну оцінки різних міжсуб'єктних взаємодій у контексті того чи іншого освітнього середовища.

Усі ці особливості, як переконливо доводить Р. Гурниковська, вказують на те, що ми маємо справу з новим процесом навчання, який повністю орієнтований на студента («особистісно орієнтована освітня ситуація» або його англійський еквівалент «studentcentered approach») (Гурниковская, 2006).

У гуманістичній інтерпретації мета освіти полягає у створенні умов для розвитку особистості, самостійного суб'єкта діяльності, що забезпечує його подальший саморух, розширить межі соціальної адаптації та успішної інтеграції в активний соціум.

Досягнення цієї мети неможливе як без включення цієї людини в соціальні відносини, так і без підтримки становлення ï індивідуальності. Л. Виготський указував на необхідність створення такої системи навчання, в якій дитина 3 обмеженими можливостями здоров'я не відокремлювалась б від дітей з нормальним розвитком (Выготский, 1983). 
Можна стверджувати, що інформатизація, з одного боку, і розвиток суспільства, сфери освіти, а також інші фактори зовнішнього середовища, 3 іншого боку, призводять до необхідності впровадження інформатики, інформаційних i телекомунікаційних технологій як інструментів інновацій, що дозволяють освіті взагалі і вищій педагогічній освіті зокрема відповідати сучасному рівню розвитку суспільства (Атанасян, 2009).

Відповідно виокремлено тенденцію інформатизації професійної підготовки майбутніх логопедів в умовах інформаційно-освітнього середовища.

Інформатизація вищої освіти тісно пов'язана 3 інформатизацією суспільства. Інформатизацію освіти можна розуміти по-різному. Інформатизація в широкому сенсі - комплекс соціально-педагогічних перетворень, пов'язаний 3 насиченням освітніх систем інформаційною продукцією, засобами і технологією; інформатизація освіти у вузькому сенсі - впровадження в установи системи освіти інформаційних засобів, заснованих на мікропроцесорній техніці, а також інформаційної продукції i педагогічних технологій, що базуються на цих засобах (Атанасян, 2009).

Упровадження інформаційних $\mathrm{i}$ телекомунікаційних технологій дозволило створити нові форми освітньої діяльності, до яких, насамперед, належить розподілене в часі й у просторі дистанційне навчання. Інформатизація торкнулася і погано формалізованих теоретичних підходів до розробки нових навчальних курсів, матеріалів і методів навчання.

Можна вважати, що у глобальному сенсі «сучасне інформаційне середовище» збігається з інформаційним суспільством. Ухвалення подібної тези означає, що вся підготовка сучасного фахівця, зокрема й логопеда, повинна бути спрямована на потреби інформаційного суспільства. Це означає, що сучасну людину необхідно вчити працювати 3 інформаційними ресурсами. Очевидно, що сучасний логопед повинен володіти певним набором якостей, пов'язаних 3 умінням здійснювати освітню діяльність 3 використанням інформаційних технологій. Інформатизація не зводиться тільки до розробки та впровадження в освітній процес технічних засобів, інформатизація стає найважливішим засобом реалізації нової освітньої парадигми, створює сприятливі умови для формування гуманітарного складника освіти, досягнення нових освітніх результатів (Гагарина, 2009).

Об'єктивним наслідком розвитку процесу інформатизації освіти та інших сфер людської діяльності стає створення інформаційно-освітнього середовища. Воно передбачає наявність певної систематичності, комплексності впровадження інформаційно-комунікаційних технологій у порівнянні 3 процесами стихійної інформатизації, властивої початковим етапам.

Головний висновок, який слід зробити 3 аналізу особливостей інформатизації суспільства та інформатизації освіти, полягає в тому, що якості підготовки фахівців до життєдіяльності в сучасному інформаційному суспільстві неможливо досягти без відповідного рівня інформатизації освіти, без створення інформаційно-освітнього середовища. Це твердження є очевидним наслідком з усього вищенаведеного викладу і обумовлене двома основними положеннями:

1. Якість сучасного навчального і виховного процесу може бути досягнута тільки в тому випадку, якщо у всіх формах і видах освітньої діяльності застосовуються інформаційні й телекомунікаційні технології, а їх застосування адекватне потребам системи освіти.

2. Інформатизація освіти, використання студентами засобів інформатизації в процесі навчання сприяє виробленню в них необхідних якостей інформаційної культури, реальному залученню майбутніх фахівців до використання інформаційних і телекомунікаційних технологій як у подальшій професійній діяльності, так і в інших сферах суспільного життя.

С. Атанасян зазначає, що інформатизація освіти, а отже, й опосередковано інформатизація суспільства, неможливі без наявності у педагогів відповідної 
інформаційної культури, знань і мотивів до застосування засобів інформатизації (Атанасян, 2009).

Інформатизація освітньої системи підготовки майбутніх логопедів $\epsilon$ багаторівневою практикою, зміст і структура якої визначаються такими основними факторами: ступенем інтеграції інформаційних технологій у майбутню сферу професійної діяльності; позиціонуванням закладу вищої освіти як освітньої системи певного типу (дослідницький університет або недержавний заклад); наявністю в більшості студентів соціально значущого досвіду використання інформаційних технологій у довузівський період; матеріально-технічною базою та кадровим потенціалом професорсько-викладацького складу ЗВО; ступенем сформованості теоретико-методологічних та організаційно-педагогічних умов інформатизації.

Висновки і перспективи подальших розвідок. Отже, визначено тенденції професійної підготовки майбутніх логопедів в умовах інформаційно-освітнього середовища закладів вищої освіти: соціально-педагогічна зумовленість процесу підготовки майбутніх логопедів, яка орієнтована на міждисциплінарну інтеграцію в освітньому процесі; фундаменталізація загальної та спеціальної підготовки майбутніх логопедів; переорієнтація зі знаннєвої освітньої парадигми на діяльнісну, орієнтовану на формування готовності майбутнього логопеда до професійної діяльності; гуманістична спрямованість процесу підготовки фахівців до освіти дітей 3 порушеннями мовлення; інформатизація професійної підготовки майбутніх логопедів в умовах інформаційно-освітнього середовища; неперервність професійної підготовки майбутніх логопедів; інноваційний характер сучасної вищої освіти. Встановлено, що сучасна ситуація соціального розвитку, соціально-педагогічні умови в системі загальної та професійної освіти визначають загальну тенденцію підготовки майбутнього логопеда до освіти дітей 3 порушеннями мовлення. В межах першої тенденції міждисциплінарну інтеграцію в освітньому процесі розуміємо як навчання і виховання дітей з порушеннями мовлення в установах загальної системи освіти разом 3 нормально розвиненими дітьми за створення відповідних умов в єдиному освітньому просторі. У межах другої тенденції ідея фундаменталізації передбачає глибину і широту загальнонаукових, філософських, загальнокультурних і спеціальних знань. Третя тенденція пов'язана із вирішенням таких основних проблем: побудови системи знань студентів, необхідної і достатньої для повноцінного оволодіння ними основами професійної діяльності; пошуку способів реалізації практичних потреб, ціннісних орієнтацій студентів у процесі формування теоретичних знань; пошуку шляхів розширення можливостей застосування теоретичних знань у практичній діяльності студентів. Четверта тенденція спрямовує орієнтування на гуманістичну стратегію у професійній підготовці фахівця у ЗВО, яку розглядаємо як принципово новий підхід, заснований на гуманізації всієї системи освіти в цілому, а також необхідності визнання існування дітей $з$ порушенням мовлення, прийняття їх як реальності, надання їм статусу повноправних його членів i, відповідно, формування професійної готовності логопеда до суб'єкт-суб'єктної взаємодії і спілкування 3 ними. У межах п'ятої тенденції розглядаємо інформатизацію освіти через сферу науково-практичної діяльності фахівця, спрямованої на застосування методів і засобів збору, зберігання, обробки й поширення інформації для систематизації наявних і формування нових знань 3 метою досягнення психолого-педагогічних цілей навчання і виховання дітей 3 порушеннями мовлення. Шоста тенденція характеризує неперервну освіту, яка спирається на базову підготовку майбутнього логопеда (знання, вміння й навички) та $\epsilon$ основою для подальшого формування готовності до професійної діяльності, а цілі підвищення кваліфікації визначаються соціальними потребами й особистими запитами. В умовах сьомої тенденції інноваційні підходи до підготовки фахівця поділяємо на два основних типи: модернізації і трансформації. До специфічних тенденцій у професійній підготовці майбутнього логопеда віднесено такі: переорієнтацію ціннісних смислів, інтенсифікацію освіти, необхідність управління 
педагогічним процесом, кризу спеціальної освіти, що складається під дією зовнішніх і внутрішніх чинників.

Перспективу подальших досліджень вбачаємо у розкритті кожної тенденції для вдосконалення професійної підготовки майбутніх логопедів в умовах інформаційноосвітнього середовища закладів вищої освіти.

\section{СПИСОК ВИКОРИСТАНИХ ДЖЕРЕЛ}

Lowton, D. (1987) The changing role of the teaching: consequences for teacher education and training. Prospects. No. 1. p. 15-18.

Shishov, S. (1997) Monitoring quality in education. Management planning of education in Russia EU - TAOS: Final reports and policy documents on quality control (higher) education. Bureau CROSS, Frederiksborg County, AF Forum. p. 23-24

Пахомова, Н. (2012). Загальнотеоретичні аспекти інтеграції педагогічних, психологічних і медичних складових професійної підготовки логопедів. Актуальні питання корекційної освіти. Серія: Педагогічні науки. Вип. 3. с. 180-188.

Шамова, Т. (2006). Управление образовательными системами: учеб. пособ. 3-е изд., стереотип. / Т. И. Шамова, Т. М. Давыденко, Г. Н. Шибанова. Москва: Академия.

Шишов, С. (2000). Школа: мониторинг качества образования / С. Е. Шишов, В. А. Кальней. Москва: Педагогическое общество России.

Султанова, Р. (2005). Формирование профессиональной компетентности будущего учителя-логопеда в учебно-педагогической, производственной практике повышенного уровня. Кандидат педагогических наук. Ижевск.

Бессмертная, Н. (2001). Организационно-педагогические условия развития профессиональной компетентности будущих логопедов сельских образовательных учреждении. Кандидат педагогических наук. Якутск.

Аслаева, Р. (2011) Стратегия сочиально-профессиональной подготовки дефектологов в педагогическом вузе. Доктор педагогических наук. Уфа.

Талызина, Н. (1986) Теоретические основы разработки модели специалиста. Москва: Знание.

Харченко, Н. (2003) Технологическая модель профессиональной подготовки логопеда в педагогическом вузе. Кандидат педагогических наук. Ставрополь.

Сластёнин, В. (1994) Гуманистическая парадигма педагогического образования. Магистр. № 6. с. 2-7.

Гурниковская, Р. (2006) Информащионно-образовательная среда общенаучной подготовки студентов гуманитарных специальностей. Кандидат педагогических наук. Ростов-на-Дону.

Выготский, Л. (1983) Собрание сочинений: в 6 m. Москва: Педагогика, Т. 3 : Проблемы развития психики /под ред. А. М. Матюшкина.

Атанасян, С. (2009) Формирование информационной образовательной среды педагогического вуза. Доктор педагогических наук. Москва.

Гагарина, Д.(2009) Высокоразвитая информационно-образовательная среда вуза как средство формирования гуманитарной составляющей высшего профессионального образования (на примере курса отечественной истории). Кандидат педагогических наук. Пермь.

\section{REFERENCES}

Lowton, D. (1987) The changing role of the teaching: consequences for teacher education and training. Prospects. No. 1. pp. 15-18.

Shishov, S. (1997) Monitoring quality in education. Management planning of education in Russia EU - TAOS: Final reports and policy documents on quality control (higher) education. Bureau CROSS, Frederiksborg County, AF Forum. pp. 23-24.

Pakhomova, N. (2012) Zagalnoteoretychní aspekty íntehratsíí pedahohíchnykh, psykholohíchnykh í medychnykh skladovykh profesíynoí pídhotovky lohopedív [The Theoretical Aspects of the Integration of Pedagogical, Psychological and Medical 
Components of Vocational Training of Speech Therapists]. Aktualni pytannya korektsíinoí osvity. Seríia: Pedahohíchní nauky. Vyp. 3. s. 180-188. (in Ukrainian)

Shamova, T. (2006). Upravleniye obrazovatelnymi sistemami [Management of Educational Systems]: ucheb. posob. 3-ye izd., stereotip. / T. I. Shamova, T. M. Davydenko \& G. N. Shibanova. Moskva: Akademiya. (in Russian)

Shishov, S. (2000). Shkola: monitoring kachestva obrazovaniya [School: Monitoring the Quality of Education]. Moskva: Pedagogicheskoye obshchestvo Rossii. (in Russian)

Sultanova, R. (2005). Formirovaniye professionalnoy kompetentnosti budushchego uchitelya-logopeda $v$ uchebno-pedagogicheskoy, proizvodstvennoy praktike povyshennogo urovnya [Formation of the Professional Competence of a Future Speech Therapist-Teacher in Educational and Pedagogical, Industrial Practice of Higher Level]. Kandidat pedagogicheskikh nauk. Izhevsk. (in Russian)

Bessmertnaya, N. (2001). Organizatsionno-pedagogicheskiye usloviya razvitiya professionalnoy kompetentnosti budushchikh logopedov selskikh obrazovate'nykh uchrezhdenii [Organizational and Pedagogical Conditions for the Development of Professional Competence of Future Speech Therapists in Rural Educational Institution]. Kandidat pedagogicheskikh nauk. Yakutsk. (in Russian)

Aslayeva, R. (2011) Strategiya sotsialno-professionalnoy podgotovki defektologov $v$ pedagogicheskom vuze [Strategy of Social and Vocational Training of Defectologists in a Pedagogical University]. Doktor pedagogicheskikh nauk. Ufa. (in Russian)

Talyzina, N. (1986) Teoreticheskiye osnovy razrabotki modeli spetsialista [Theoretical Foundations for the Development of a Specialist Model]. Moskva: Znaniye.

Kharchenko, N. (2003). Tekhnologicheskaya model professionalnoy podgotovki logopeda v pedagogicheskom vuze [Technological Model of Vocational Therapist Training at Pedagogical University]. Kandidat pedagogicheskikh nauk. Stavropol. (in Russian)

Slastonin, V. (1994). Gumanisticheskaya paradigma pedagogicheskogo obrazovaniya [The Humanistic Paradigm of Pedagogical Education]. Magistr. No 6. s. 2-7. (in Russian)

Gurnikovskaya, R. (2006). Informatsionno-obrazovatelnaya sreda obshchenauchnoy podgotovki studentov gumanitarnykh spetsialnostey [Information and Educational Environment of General Scientific Training of Students of Humanitarian Specialties]. Kandidat pedagogicheskikh nauk. Rostov-na-Donu. (in Russian)

Vygotskiy, L. (1983). Sobraniye sochineniy [Collected Works]: v 6 t. Moskva: Pedagogika, T. 3: Problemy razvitiya psikhiki /red. A. M. Matyushkina. (in Russian)

Atanasyan, S. (2009). Formirovaniye informatsionnoy obrazovatelnoy sredy pedagogicheskogo vuza [Formation of the Information Educational Environment in Pedagogical University]. Doktor pedagogicheskikh nauk. Moskva. (in Russian)

Gagarina, D. (2009). Vysokorazvitaya informatsionno-obrazovatel'naya sreda vuza kak sredstvo formirovaniya gumanitarnoy sostavlyayushchey vysshego professional'nogo obrazovaniya (na primere kursa otechestvennoy istorii) [The Highly Developed Information and Educational Environment of the University as a Means of Formation the Humanitarian Component of Higher Professional Education (for example, the course of Russian history)]. Kandidat pedagogicheskikh nauk. Perm. (in Russian)

\section{PROFESSIONAL TRAINING TENDENCIES OF FUTURE SPEECH THERAPISTS IN THE CONTEXT OF INFORMATIONAL AND EDUCATIONAL ENVIRONMENT OF HIGHER EDUCATIONAL INSTITUTIONS}

Svitlana Tsymbal-Slatvinska Candidate of Pedagogical Sciences (Ph(D), Associate Professor, Assocaite Professor at the Department of Special Education,

Uman PavloTychyna State Pedagogical University,

Uman, Ukraine

ORCID: 0000-0002-2732-5716

e-mail: lanatsimbal@gmail.com 


\begin{abstract}
The article deals with professional training tendencies of future speech therapists in the conditions of informational and educational environment of a higher educational institutions: social and pedagogical conditions for the future speech therapists professional training focused on interdisciplinary integration into the educational process; fundamentalization of future speech therapists general and specific training; reorientation from the knowledge educational paradigm to active and focused on the future speech pathologist's readiness shaping for professional activity; humanistic orientation of the specialists in the education of children with speech disorders training; informatization of future speech therapists professional training in the conditions of informational and educational environment; continuity of future speech therapists professional training; innovative nature of modern higher education. Current situation of social development, social and pedagogical conditions in the system of general and professional education are stated to characterize general tendency of future speech therapists training for teaching children with speech disorders. In the framework of the first tendency, interdisciplinary integration in the educational process is understood as the education and upbringing of children with speech impairments in institutions of the general education system, together with normally developed children, in order to create appropriate conditions in a single educational space. In the second trend, the idea of fundamentalization implies the depth and breadth of general scientific, philosophical, general cultural and specialized knowledge. The third tendency is related to the solution of two main problems: building a system of students' knowledge that is necessary and sufficient for their mastering basics of professional activity; search of ways of realization of practical needs, value orientations of students in the process of theoretical knowledge formation; finding ways to expand the use of theoretical knowledge in students' practical work. The fourth trend is to focus on a humanistic strategy in professional training at a higher education institution, which is seen as a fundamentally new approach based on the humanization of the entire education system as a whole, as well as the need to recognize the existence of children with speech impairment, to accept them as a reality, to be a given society, to give them the status of full members and, accordingly, to form a professional readiness of speech therapist for subject and subjective interaction and communication with them. In the framework of the fifth tendency we consider informatization of education through the sphere of scientific and practical activity of a specialist, aimed at applying methods and means of collecting, storing, processing and disseminating information for systematization of existing and formation of new knowledge in the framework of achievement of psychological and pedagogical goals of education and upbringing children with speech disorders. The sixth trend is characterized by continuous education, which is based on the future speech therapist basic training (knowledge, skills), and is the basis for further formation of readiness for professional activity, and the goals of professional development are determined by social needs and personal requests. In the context of the seventh trend, innovative approaches to specialist training are divided into two main types: modernization and transformation.
\end{abstract}

Keywords: tendencies, professional training, future speech therapists, interdisciplinary integration, fundamentalization, humanistic orientation, informatization, continuity.

Стаття надійшла до редакиії 27.09.2019 р. 